International Journal of Advances in Pharmacy and Biotechnology

Vol.1, Issue-2, 2015, 1-8

Research Article

I J A P B

Open Access

\title{
Isolation and Purification of Exopolysaccharides and Exploring its Potential as an Excipient in the Development of Suitable Formulation
}

\author{
Gadad A.P.*1, Sharma Vani' ${ }^{1}$, Darbha N.S. ${ }^{2}$, Dandagi P.M. ${ }^{1}$, Singh Renu ${ }^{1}$ \\ 1Department of Pharmaceutics, KLEU'S College of Pharmacy, \\ KLE University, Belgaum-590010, Karnataka, India. \\ 2Department of Pharmaceutical Biotechnology, KLEU'S College of Pharmacy, \\ KLE University, Belgaum-590010, Karnataka, India. \\ *Corresponding author e-mail: gadadap@rediffmail.com
}

\begin{abstract}
Received: 23 August 2015
Revised: 05 September 2015

Accepted: 29 September 2015

ABSTRACT:

Exopolysaccharides (EPS) are high-molecular-weight polymers, excreted by some microorganisms onto the outside of their cell walls. EPS are primarily composed of carbohydrate and some non-carbohydrate substituents, such as acetate, phosphate, pyruvate and succinate. The study was aimed at isolation of EPS from pseudomonas strains and milk samples and also preliminary trials were carried with sea water, sea sediment and soil samples. Based on the trial study pseudomonas and milk sample (lactobacilli) were selected for EPS production. The pseudomonas strains were then subcultured in cetrimide media and lactic acid bacteria strains were subcultured in milk media (50\%) supplied with $50 \%$ carbohydrate source maintained at $20^{\circ} \mathrm{C}$ for 72 hours. The EPS obtained from milk sample was highly viscous in nature, good smelling and high yield. The EPS obtained from pseudomonas strains didn't show satisfactory yield. The EPS obtained from lactobacilli was characterized and used as gelling agent in formulating a Diclofenac diethylamine gel. The formulated gel was evaluated and compared to marketed formulation for gelling agent, consistency and performance.
\end{abstract}

Key words: Exopolysaccharides, Pseudomonas, lactobacilli, Gelling agent.

\section{INTRODUCTION}

Bacterial EPSs are biopolymers that are secreted by the cells and form a capsule that remains associated with the cell surface or a slime that is loosely bound to the cell surface. These biopolymers are mainly composed of carbohydrates, with glucose, galactose and mannose being the most common monomers. There has been a marked upsurge of interest and steady increase in the exploitation of microbial exopolysaccharide due to their unique and novel properties. The physicochemical properties of polysaccharide solutions are providing a new insight into the physical structures of these polymers and furnishing the industrialist with clearer indication of their useful properties. The greatest potential of bacterial EPS is related to their use in high value market niches, such as cosmetics, pharmaceuticals and biomedicine, pharmacological, nutraceutical, functional food, herbicides and insecticides in which traditional polymers fail to comply. The increased interest in microbial polysaccharides reflects a growth in the use of water soluble polymers and also an appreciation of the environmental advantages to be gained from use of water soluble rather than solvent based systems ${ }^{[1,2]}$. The overwhelming diversity of bacterial polysaccharides allows for categorization based on chemical structure, functionality, molecular weight and linkage bonds ${ }^{[3,4]}$. The diversity of bacterial polysaccharides allows for categorization based on chemical structure, functionality, molecular weight and linkage bonds. Extracellular polysaccharides show considerable diversity in their composition and structure and are synthesized by bacteria of all taxa. Exopolysaccharides occur widely, especially 
among prokaryotic species but they are less common among yeasts and fungi[5].

Few microbial genera form components of more complex structures which may be involved in different morphogenetic cycles such as those found in the families Azotobacteriaceae and Myxobacteriaceae. In each of these bacterial groups, exopolysaccharides are associated with normal vegetative cells and with resting cells in the form of microcysts. The presence of exopolysaccharides associated with microbial cells grown on solid surfaces is frequently recognizable from the mucoid colony morphology. In liquid medium, EPS producing cultures may become very viscous exceptionally, may solidify as a gel. The EPS may form part of a capsulefirmly attached to the bacterial cell surface or it may be observed as loose slime secreted by the microorganisms but not directly attached to the cell. On solid surfaces exposed to aqueous environments, fresh water or the oceans bacterial growth is seen as biofilms in which the microbial cells are associated with large amounts of EPS[1].

Polysaccharides have a number of applications in the formulation of pharmaceutical products (Table 1). They are incorporated into lotions and gels to impart specific rheological properties to the preparations. The materials used are mainly of plant or algal origin, including alginate but various microbial polysaccharides, including xanthan, may also find such uses. The shearthinning capabilities of xanthan have caused it to be used in some toothpaste, where it permits the product to be readily squeezed from a tube and regain its viscosity on leaving the container. New gel-forming microbial products such as gellan clearly have potential uses in the pharmaceutical area, as do polymers capable of forming coacervates with gelatin, etc ${ }^{1}$.This research interest in bacterial production of exopolysaccharides aims for production of polymers with finetuned properties and exploring its potential as an excipient in the development of suitable formulation.

\section{MATERIALS AND METHODS Materials}

King's medium B Base, Cetrimide media, Azotobacter media, MRS media, Glucose, Lactose were procured from $\mathrm{Hi}$ Media laboratories, Mumbai. Diclofenac Diethyl amine was obtained from Themis Pharma, Haridwar. Trichloro acetic acid was obtained from Merck specialities Pvt. Ltd., Mumbai; phenol, sulphuric acid, isopropyl alcohol, propyl paraben, methyl paraben, sodium hydroxide and ethanol were of analytical grade.

\section{Isolation and Production of Exopolysaccharides Strain, media and growth conditions}

For the isolation of Pseudomonas, various sea sediment samples, marine water samples and soil samples were collected and screened in Cetrimide agar. For the isolation of LAB various marketed milk and curd samples were utilized for the growth of lactobacilli on skim milk media (Fig. 1). The pseudomonas strains were then subcultured in cetrimide media and lactic acid bacteria strains were subcultured in milk media (50\%) supplied with $50 \%$ carbohydrate source (Table 2 ). The bacteria were then screened for their ability to produce exopolysaccharide, based on the colony morphology (Mucous and Ropy).

\section{Isolation of EPS}

For the isolation of EPS the media was heated to $90-100^{\circ} \mathrm{C}$ to kill the EPS degrading enzymes. The protein and cells were initially precipitated by the addition of $5 \%(\mathrm{w} / \mathrm{v})$ trichloroacetic acid (TCA) to the culture; the mixture was then stirred for 4 hours. After centrifugation (5000 rpm at $4^{\circ} \mathrm{C}$ for $20 \mathrm{~min}$ ), cold ethanol was gradually added to the supernatant and followed by intermediate centrifugation. The exopolysaccharide precipitate was collected after centrifugation at $5000 \mathrm{rpm}$. EPS production from pseudomonas was not enough so as to use it in formulation development; hence EPS obtained from lactic acid bacteria was formulated in gel as a gelling agent. 
Table 1: Physicochemical and functional properties, main areas of application and market assessment of EPS ${ }^{[2]}$

\begin{tabular}{|c|c|c|c|c|c|c|}
\hline EPS & Components & Charge & $\begin{array}{c}\text { Molecular } \\
\text { weight }\end{array}$ & Main properties & Main applications & $\begin{array}{c}\text { Price } \\
\text { (US\$)/kg }\end{array}$ \\
\hline Xanthan & $\begin{array}{l}\text { Glucose } \\
\text { Mannose } \\
\text { Glucuronic acid } \\
\text { Acetate } \\
\text { Pyruvate }\end{array}$ & Anionic & $(2.0-50) \times 10^{6}$ & $\begin{array}{l}\text { Hydrocolloid } \\
\text { High viscosity yield } \\
\text { at low shear rates even } \\
\text { at low concentrations; } \\
\text { Stability over wide } \\
\text { temperature, pH. }\end{array}$ & $\begin{array}{l}\text { Foods } \\
\text { Petroleum industry } \\
\text { Pharmaceutical } \\
\text { Cosmetics and personal } \\
\text { care products }\end{array}$ & $3-5$ \\
\hline Gellan & $\begin{array}{l}\text { Glucose } \\
\text { Rhamnose } \\
\text { Glucuronic acid } \\
\text { Acetate } \\
\text { Glycerate }\end{array}$ & Anionic & $5.0 \times 10^{5}$ & $\begin{array}{l}\text { Hydrocolloid } \\
\text { Stability over wide } \\
\text { pH range } \\
\text { Gelling capacity } \\
\text { Thermoreversible gels }\end{array}$ & $\begin{array}{l}\text { Foods } \\
\text { Pet food } \\
\text { Pharmaceutical } \\
\text { gar substitute } \\
\text { and gel electrophoresis }\end{array}$ & $55-66$ \\
\hline Alginate & $\begin{array}{l}\text { Guluronic acid } \\
\text { Mannuronic acid } \\
\text { Acetate }\end{array}$ & Anionic & $(0.3-1.3) \times 10^{6}$ & $\begin{array}{l}\text { Hydrocolloid } \\
\text { Gellling capacity } \\
\text { Film-forming }\end{array}$ & $\begin{array}{l}\text { Food hydrocolloid } \\
\text { Medicine } \\
\text { Surgical dressings } \\
\text { Wound management } \\
\text { Controlled drug }\end{array}$ & $5-20$ \\
\hline Cellulose & Glucose & Neutral & $10^{6}$ & $\begin{array}{l}\text { High crystallinity } \\
\text { Insolubility } \\
\text { in most solvents } \\
\text { High tensile strength } \\
\text { Moldability }\end{array}$ & $\begin{array}{l}\text { Foods (indigestible fiber) } \\
\text { Wound healing } \\
\text { Tissue engineered } \\
\text { blood vessels } \\
\text { Diaphragms }\end{array}$ & $5.8-12$ \\
\hline Dextran & Glucose & Neutral & $10^{6}-10^{9}$ & $\begin{array}{l}\text { Non-ionic } \\
\text { Good stability } \\
\text { Newtonian } \\
\text { fluid behavior }\end{array}$ & $\begin{array}{l}\text { Foods } \\
\text { Pharmaceutical industry: } \\
\text { Blood volume expander } \\
\text { Chromatographic media }\end{array}$ & N.A. \\
\hline Curdlan & Glucose & Neutral & $5 \times 10^{4}-2 \times 10^{6}$ & $\begin{array}{l}\text { Gel-forming ability } \\
\text { Water insolubility } \\
\text { Edible and non-toxic } \\
\text { Biological activity }\end{array}$ & $\begin{array}{l}\text { Foods } \\
\text { Pharmaceutical industry } \\
\text { Heavy metal removal }\end{array}$ & 55 \\
\hline Hyaluronan & $\begin{array}{l}\text { Glucuronic acid } \\
\text { Acetyl glucosmine }\end{array}$ & Anionic & $2.0 \times 10^{6}$ & $\begin{array}{l}\text { Biological activity } \\
\text { Highly hydrophilic } \\
\text { Biocompatible }\end{array}$ & $\begin{array}{l}\text { Medicine } \\
\text { Solid culture media }\end{array}$ & 100000 \\
\hline Succinoglycan & $\begin{array}{l}\text { Glucose, Galactose } \\
\text { Acetate, Pyruvate } \\
\text { 3hydroxybutyrate }\end{array}$ & Anionic & $\begin{array}{l}\text { LMW < }<\times 10^{3} \\
\text { HMW }>1 \times 10^{6}\end{array}$ & $\begin{array}{l}\text { Viscous shear thinning } \\
\text { aqueous solutions } \\
\text { Acid stability }\end{array}$ & $\begin{array}{l}\text { Food } \\
\text { Oil recovery }\end{array}$ & N.A. \\
\hline Levan & Fructose & Neutral & $3.0 \times 10^{6}$ & $\begin{array}{l}\text { High water solubility } \\
\text { Anti-tumor activity } \\
\text { Anti-inflammatory } \\
\text { Adhesive strength } \\
\text { Film-forming capacity }\end{array}$ & $\begin{array}{l}\text { Food (prebiotic) } \\
\text { Feed } \\
\text { Medicines } \\
\text { Cosmetics Industry }\end{array}$ & N.A. \\
\hline GalactoPol & $\begin{array}{l}\text { Galactose } \\
\text { Mannose } \\
\text { Glucose } \\
\text { Rhamnose } \\
\text { Acetate, Pyruvate } \\
\text { Succinate }\end{array}$ & Anionic & $(1.0-5.0) \times 10^{6}$ & $\begin{array}{l}\text { Viscous shear thinning } \\
\text { solutions in } \\
\text { aqueous media } \\
\text { Film-forming } \\
\text { Emulsifying capacity } \\
\text { Flocculating capacity }\end{array}$ & $\begin{array}{l}\text { Food and feed } \\
\text { Cosmetics } \\
\text { Pharmaceuticals } \\
\text { and medicine } \\
\text { Oil recovery }\end{array}$ & - \\
\hline FucoPol & $\begin{array}{l}\text { Fucose } \\
\text { Galactose } \\
\text { Glucose } \\
\text { Acetate } \\
\text { Succinate } \\
\text { Pyruvate } \\
\end{array}$ & Anionic & $(2.0-10.0) \times 10^{6}$ & $\begin{array}{l}\text { shear thinning } \\
\text { Film-forming } \\
\text { Emulsifying capacity } \\
\text { Flocculating capacity } \\
\text { Biological activity }\end{array}$ & $\begin{array}{l}\text { Cosmetics } \\
\text { Pharmaceuticals } \\
\text { and medicine } \\
\text { Oil recovery } \\
\text { Source of fucose and } \\
\text { fuco oligosaccharides }\end{array}$ & - \\
\hline
\end{tabular}


Table 2: Different media and strains used for the growth of EPS

\begin{tabular}{llccccccc}
\hline & \multicolumn{1}{c}{ Strains } \\
\cline { 2 - 7 } & \multicolumn{1}{c}{ S No. } & \multicolumn{1}{c}{$\begin{array}{c}\text { Pseudomonas } \\
\text { fluorescens }\end{array}$} & $\begin{array}{c}\text { Pseudomonas } \\
\text { putida }\end{array}$ & $\begin{array}{c}\text { Pseudomonas } \\
\text { syringae }\end{array}$ & $\begin{array}{c}\text { Soil } \\
\text { sample }\end{array}$ & $\begin{array}{c}\text { Sea } \\
\text { water }\end{array}$ & $\begin{array}{c}\text { Sea } \\
\text { sediment }\end{array}$ & $\begin{array}{c}\text { Milk } \\
\text { sample }\end{array}$ \\
\hline 1. & Cetrimide media & + & + & + & - & - & - & $\mathrm{NS}$ \\
2. & King's B medium base & ++ & + & + & + & + & + & $\mathrm{NS}$ \\
3. & Azotobacter media & - & - & - & + & + & + & $\mathrm{NS}$ \\
4. & Coconut water & - & - & - & - & - & - & + \\
5. & MRS media & $\mathrm{NS}$ & $\mathrm{NS}$ & $\mathrm{NS}$ & $\mathrm{NS}$ & $\mathrm{NS}$ & $\mathrm{NS}$ & + \\
6. & Milk media & $\mathrm{NS}$ & $\mathrm{NS}$ & $\mathrm{NS}$ & $\mathrm{NS}$ & $\mathrm{NS}$ & $\mathrm{NS}$ & +++ \\
\hline
\end{tabular}

+++ high growth, ++ moderate growth, + less growth, - no growth, NS: Not studied

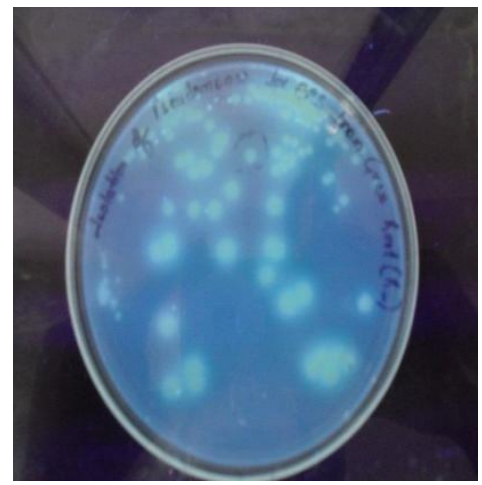

Screening of Pseudomonas from soil (UV 365nm)

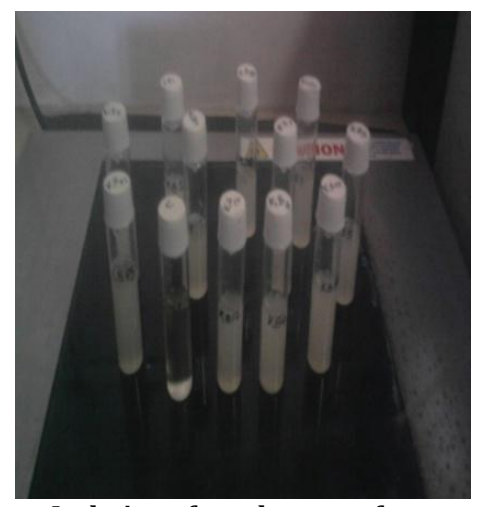

Isolation of peudomonas from coconut water

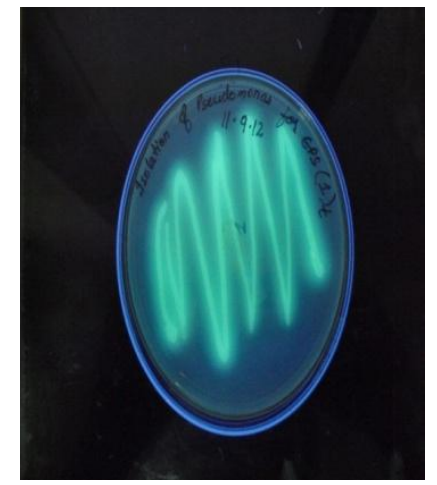

Isolation of Pseudomonas from soil (UV 365nm)

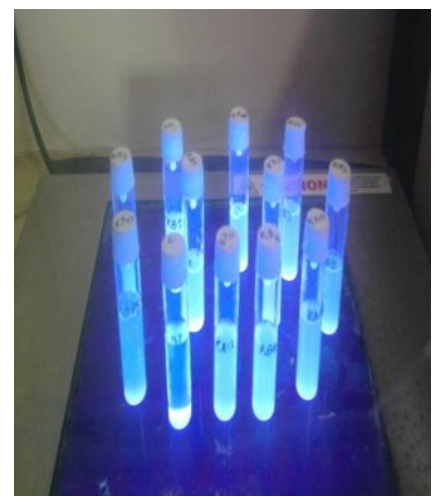

Isolation of peudomonas from coconut water (UV $365 \mathrm{~nm}$ )

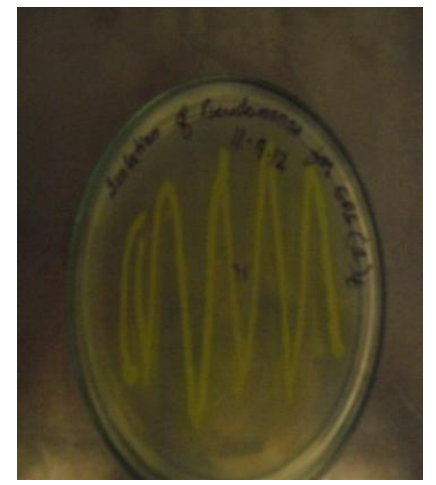

Isolation of Pseudomonas from soil

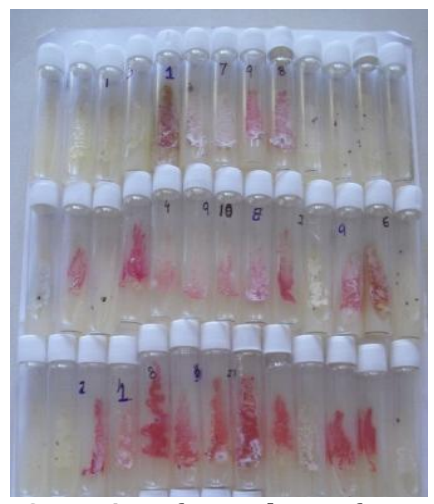

Screening of Azotobacter from sea sediment

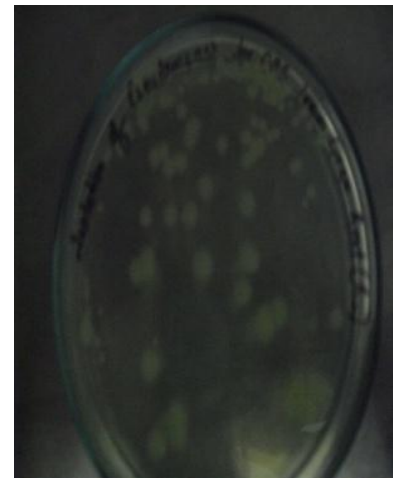

Screening of Pseudomonas from soil

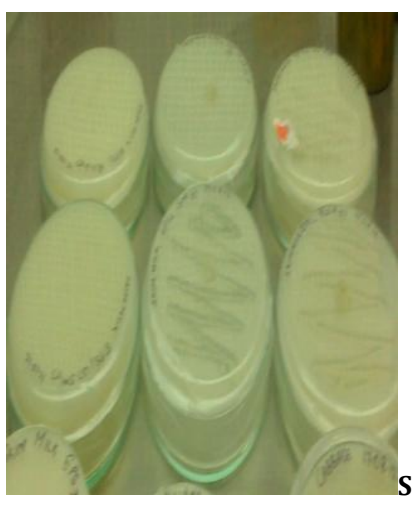

creening and isolation of $L A B$ from milk samples

Figure 1: Screening \& isolation of various Strains for EPS growth

\section{Characterization of exopolysaccharides}

The exopolysaccharide obtained were then characterized for Colour, Solubility, $\mathrm{pH}$, Carbohydrates test. Total carbohydrate content was determined by phenol sulphuric acid method, glucose was used as a standard and absorbance determined at $490 \mathrm{~nm}$ (Table $3)$. EPS obtained from milk media (50\%) supplied with $50 \%$ glucose was showing high production of EPS at temperature $20^{\circ} \mathrm{C}$. The FT-IR spectrum of EPS from Lactobacillus was carried out to confirm the identity of exopolysaccharides (Fig.2). FTIR spectra confirmed the presence of functional groups like carbohydrate ring, mannose and Dglucose in pyranose form[6,7].

\section{Formulation of Diclofenac Diethylamine gel}

\section{Compatibility studies of Drug and EPS}

Prior to the development of the dosage forms the pre-formulation study was carried out. The compatibility studies of drug, polymer and the physical mixture (1:1) of both drug 
and polymer were carried out by $\mathrm{KBr}$ disc method in the scanning range of $400-4000$ $\mathrm{cm}^{-1}$ using Fourier Transform Infrared Spectrophotometer (Shimadzu FT-IR 8400-S).

Table 3: Characterization of Exopolysaccharides

\begin{tabular}{lll}
\hline Characteristics & EPS from lactic acid bacteria & EPS from pseudomonas \\
\hline pH & 3.6 & 3.8 \\
Color & Creamy white & yellow \\
Solubility & $\begin{array}{l}\text { Soluble in water, insoluble in organic } \\
\text { solvents }\end{array}$ & $\begin{array}{l}\text { Soluble in water, insoluble in } \\
\text { organic solvents }\end{array}$ \\
$\begin{array}{l}\text { Test for Carbohydrates } \\
\text { (Molish's test) }\end{array}$ & Positive & Positive \\
$\begin{array}{l}\text { Total Carbohydrates } \\
\text { (Phenol sulphuric acid method) }\end{array}$ & $2 \mathrm{~g} / \mathrm{L}$ & $20 \mathrm{mg} / \mathrm{L}$ \\
\hline
\end{tabular}

Preparation of Diclofenac Diethylamine gel[8]

For the preparation of gel sufficient quantity of water was taken and heated up to $80-90^{\circ} \mathrm{C}$, to this methyl paraben and propyl paraben were added. After some time (slightly cool) EPS was added with continuous stirring.
Diclofenac diethylamine was weighed and dissolved in isopropyl alcohol until a clear solution was obtained. To the polymeric solution prepared drug solution was added and stirred continuously until the gel was formed. Volume was made up and $\mathrm{pH}$ was maintained using 10M NaOH. (Table 4)

Table 4: Composition of topical gel of Diclofenac diethylamine with different concentration of EPS

\begin{tabular}{lllll}
\hline Ingredients & P1 & P2 & P3 & P4 \\
\hline Diclofenac Diethylamine & 1.16 & 1.16 & 1.16 & 1.16 \\
EPS & 5 & 7.5 & 10 & 12.5 \\
Isopropyl alcohol & 10 & 10 & 10 & 10 \\
Propyl paraben & 0.25 & 0.25 & 0.25 & 0.25 \\
Methyl paraben & 0.75 & 0.75 & 0.75 & 0.75 \\
Sodium hydroxide & Q.S & Q.S & Q.S & Q.S \\
Distilled water & Q.S & Q.S & Q.S & Q.S \\
Total weight & 100 & 100 & 100 & 100 \\
\hline
\end{tabular}

\section{Evaluation of Diclofenac Diethylamine gel Characterization of gel}

Gel formulations of exopolysaccharides containing Diclofenac Diethylamine were characterized for appearance, $\mathrm{pH}$, homogeneity, spreadability, Extrudability and viscosity.

\section{Drug content ${ }^{[9,10]}$}

The drug content was determined using Phosphate Buffer ( $\mathrm{pH}$ 6.8) solution. The absorbance of the solution was measured using UV spectrophotometer. The measurement was done in triplicate and average values were calculated.

\section{In vitro drug release ${ }^{[9,10]}$}

In vitro release studies were performed using dialysis membrane (Hi-media, Mumbai, India) having molecular weight cut off between
$12,000-14,000$ D. Membrane was activated with $1 \%$ of $\mathrm{HCl}$ solution for $12 \mathrm{hrs}$. The dissolution medium used was freshly prepared phosphate buffer $\mathrm{pH}$ 6.8. Dialysis membrane, previously soaked overnight, was tied to one end of a specially designed glass cylinder (open at both ends). $5 \mathrm{ml}$ of formulation was accurately placed into this assembly. The cylinder was attached to a stand and suspended in $100 \mathrm{ml}$ of dissolution medium maintained at $37 \pm 5^{\circ} \mathrm{C}$ so that the membrane just touched the receptor medium surface. The dissolution medium was stirred at low speed using magnetic stirrer. An aliquot of $5 \mathrm{ml}$ of the sample was withdrawn from receiver compartment at predetermined time intervals and replenished with fresh medium. Samples were analyzed by UVVisible spectrophotometer at a wavelength of $275 \mathrm{~nm}$. Data obtained from in vitro release 
studies were fitted to various kinetic equations to find out the mechanism of Diclofenac Diethylamine release from gel.

\section{RESULTS AND DISCUSSION Compatibility studies:}

FTIR identification results of Diclofenac Diethylamine indicated the purity the drug also the IR spectra of pure drug, and 1:1 ratio of drug and EPS was identical and did not show any incompatibility, thus it can be suggested that EPS was compatible with the drug (Fig. 3).

\section{Evaluation of Gel}

The prepared gel showed creamy white appearance with $\mathrm{pH}$ 6.6-6.8. The evaluation parameters for the gel prepared using exopolysaccharide are summarized in Table no. 5

Table5: Evaluation physicochemical parameters of formulation of Diclofenac diethylamine gel

\begin{tabular}{cccccccc}
\hline $\begin{array}{c}\text { Formulation } \\
\text { Codes }\end{array}$ & Appearance & pH ${ }^{*}$ Homogeneity* & $\begin{array}{c}\text { Spreadability } \\
\text { (gm.cm/sec) } \\
\text { Mean } \pm \text { S.D }\end{array}$ & $\begin{array}{c}\text { Extrudability* } \\
\text { (gm) }\end{array}$ & $\begin{array}{c}\text { Viscosity* } \\
\text { (cps) } \\
\text { Mean } \pm \text { S.D. }\end{array}$ & $\begin{array}{c}\text { Drug } \\
\text { Content } \\
\text { Mean } \pm \text { S.D }\end{array}$ \\
\hline P1 & Creamy white & $6.7 \pm 0.2$ & GOOD & $50.12 \pm 0.220$ & $16.15 \pm 0.27$ & $1200 \pm 0.201$ & $87.03 \pm 0.121$ \\
P2 & Creamy white & $6.8 \pm 0.4$ & GOOD & $40.16 \pm 0.112$ & $16.75 \pm 0.33$ & $19000 \pm 0.020$ & $90.89 \pm 0.327$ \\
P3 & Creamy white & $6.7 \pm 0.4$ & GOOD & $29.12 \pm 0.542$ & $17.10 \pm 0.26$ & $35000 \pm 0.11$ & $88.831 \pm 0.031$ \\
P4 & Creamy white & $6.6 \pm 0.3$ & GOOD & $27.11 \pm 0.129$ & $17.50 \pm 0.39$ & $51032 \pm 0.34190 .241 \pm 0.0112$ \\
Marketed & Creamy white & $6.7 \pm 00.2$ & GOOD & $30.14 \pm 0.112$ & $17.90 \pm 0.43$ & $51000 \pm 0.11891 .238 \pm 0.110$ \\
\hline
\end{tabular}

\section{Drug content}

The percent drug content of all the topical formulations were found to be in the range $87.03 \pm 0.121$ to $90.24 \pm 0.112 \%$. This showed that drug was uniformly distributed in the formulated gels.

\section{In vitro drug diffusion studies}

Diffusion study of the gel of Diclofenac Diethylamine was performed using dialysis membrane in PBS pH 6.8 as the diffusion medium, the total amount of drug release was observed at different time interval for a period of $120 \mathrm{~min}$. The formulation showed good diffusion (97.34\%), given in Fig. 4.

\section{In vitro Drug Release Kinetic}

The release data were fitted to various kinetic models in order to calculate the release constant and regression coefficients $\left(R^{2}\right)$ Among the models tested, the drug release profiles for formulations were best fitted with Higuchi Matrix model based on regression coefficients.The linearity of the plot indicated that the release process was diffusion controlled. Thus, the amount of drug released was dependant on the matrix drug load.

\section{CONCLUSION}

Exopolysaccharides (EPS) obtained from Pseudomonas and lactobacilli were isolated from cetrimide media and different milk samples respectively. The EPS obtained from lactic acid bacteria was highly viscous in nature and further studied for its application in pharmaceutical formulation development. The EPS was used in different concentration and was formulated as gelling agent in Diclofenac Diethylamine gel formulation. The gelling properties of EPS was evaluated and compared with marketed formulation. As the concentration of EPS was increased the viscosity, extrudability, and consistency was found to be increased. All the formulations showed good in vitro release profile among which formulation P4 having 12.5\% EPS concentration showed maximum release, when compared with marketed formulation it showed equivalent release profile.

Further purification of exopolysaccharides is required which can enhance the properties of EPS. Hence it can be suggested that there is great need to explore the potential of exopolysaccharides as excipient in different formulations such as emulsion, gel, beads, solid dispersions and in cosmetics such as creams and lotions, as it has already been suggested in literature that EPS possess novel and physiochemical properties such as emulsifying, stabilizing, binding, gelling agents, lubricants and thickening agents. 


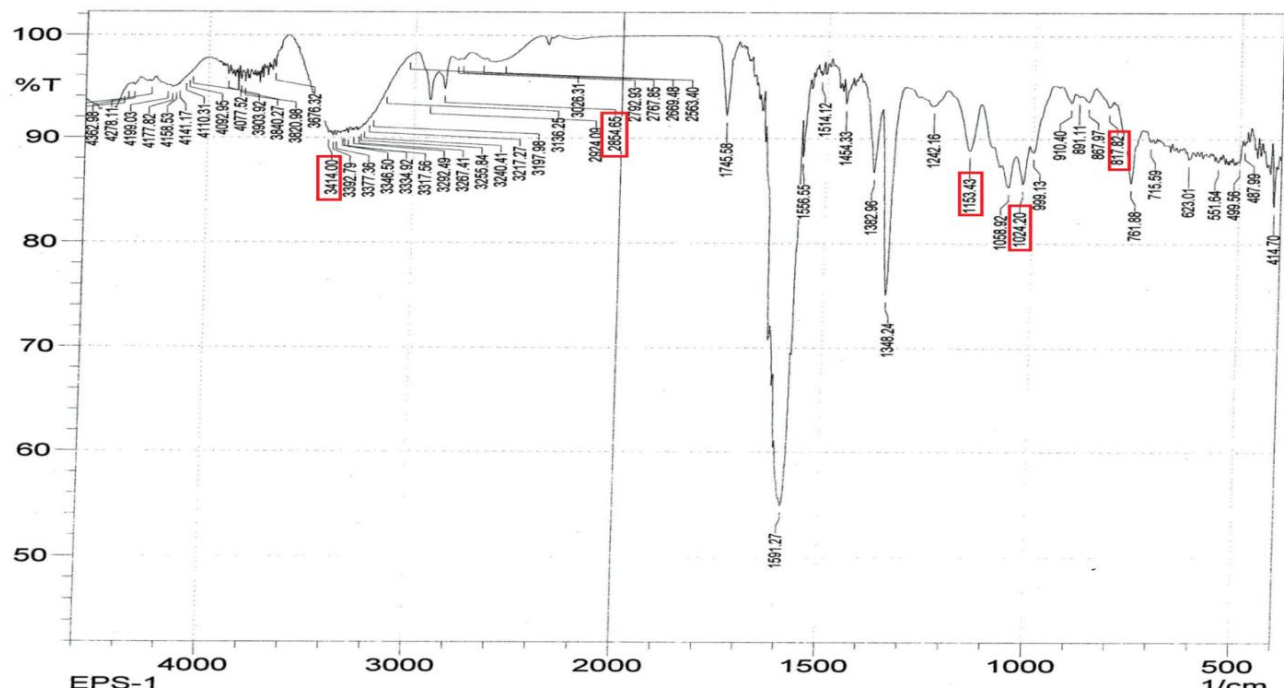

Figure 2: FTIR spectra of EPS from LAB

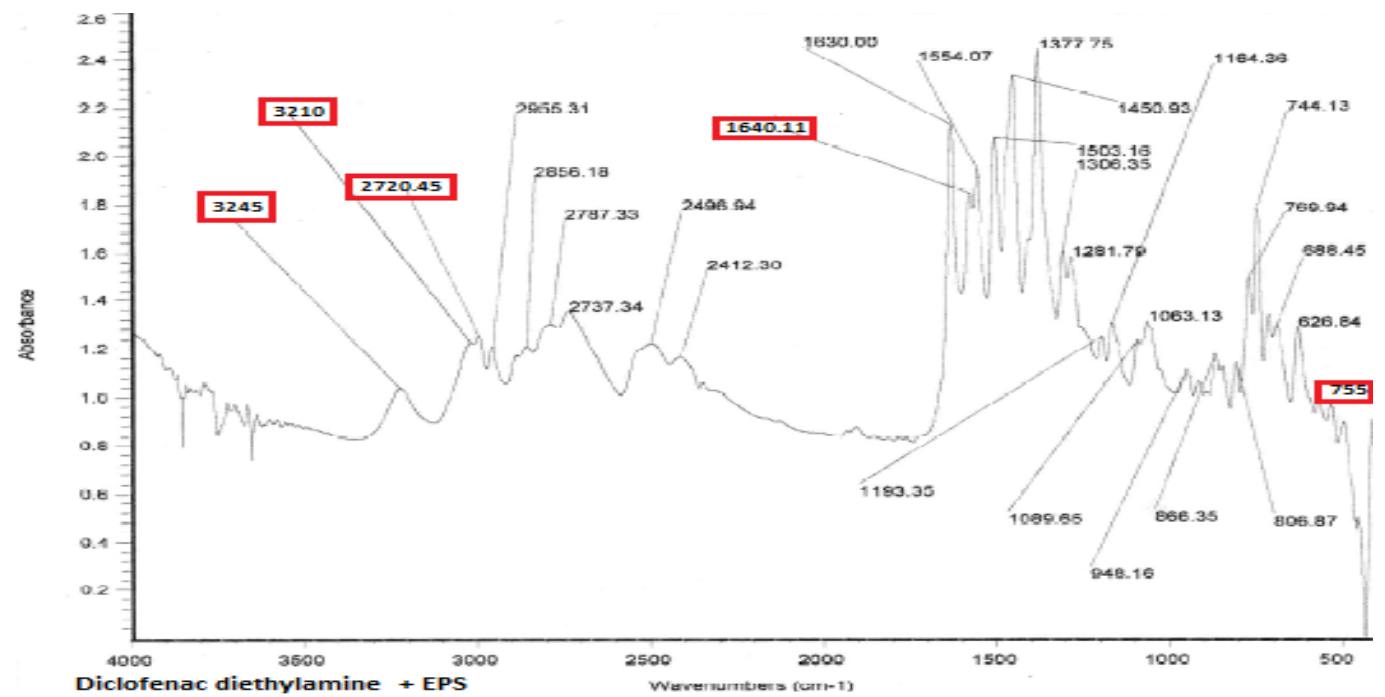

Figure 3: FTIR spectra of Diclofenac Diethylamine + EPS

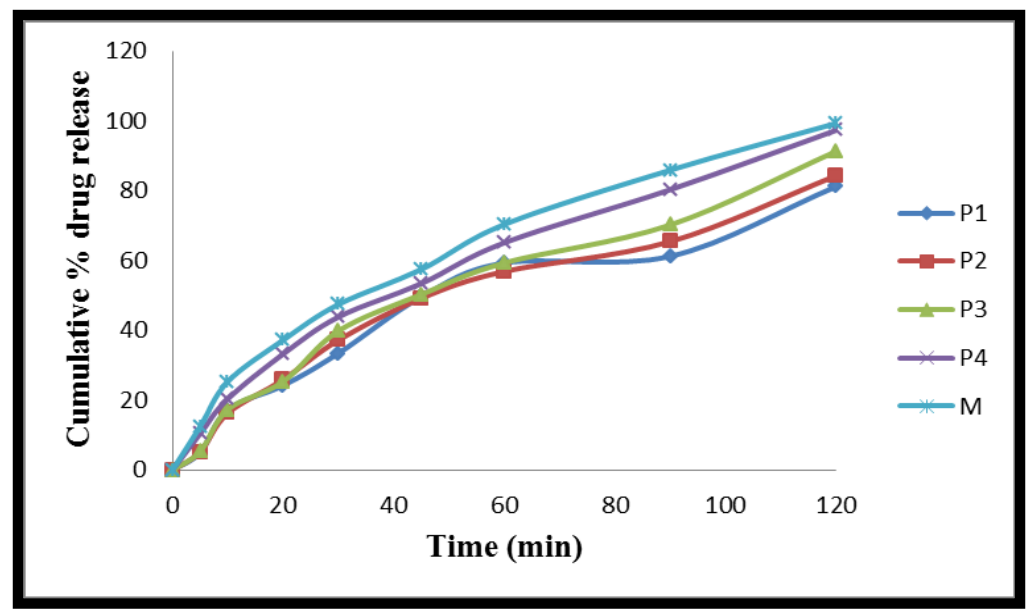

Figure 4: Cumulative drug release profile of all the formulations 


\section{REFERENCES}

1. Ian W. Biotechnology of microbial exopolysaccharides. Sutherland Department of Microbiology. New York: Edinburgh University: 1-157.

2. Freitas F, Alves VD \& Reis MAM. Advances in bacterial exopolysaccharides: from production to biotechnological applications. Trends in Biotech. 2011; 29(8): 388-398.

3. Manjanna K M, Shivakumar B \& Pramodkumar T M. Natural exopolysaccharides as novel excipients in drug delivery: A review. Arc AplSci Res. 2009; 1(2): 230-253.

4. Nwodo UU, Green E \& Okoh A I. Bacterial exopolysaccharides: functionality and prospects. Int. J. Mol. Sci. 2012; 13: 14002-14015.

5. Mozzi F, Vaningelgem F, Hebert EM, Meulen RV, Moreno MRF. Diversity of heteropolysaccharide-producing lactic acid bacterium strains and their biopolymers. Applied Environ Micro. 2006; 72(6): 4431-4435.

6. Bragadeeswaran S, Jeevapriya $\mathrm{R}$, Prabhu K, Sophia Rani S, Priyadharsini S and Balasubramanian T. Exopolysaccharide production by Bacillus cereus GU812900, a fouling marine bacterium. Afr. J. Microbiol. Res. 2011; 5(24): 4124-4132.

7. Lim J.M., Joo J.H., Kim H.O., Kim H.M., Kim S.W. Structural analysis and molecular characterization of exopolysaccharides produced by submerged mycelial culture of Collybiamaculata TG-1. Carbohydr. Pol. 2005; 61: 296-303.

8. Patel R P, Patel H H \& Baria A. Formulation and Evaluation of Carbopol Gel Containing Liposomes of Ketoconazole (Part-II). Int. J. Drug Deliv. Tech. 2009; 1(2): 42-45.

9. Shivhare U D, Jain K B, Mathur V B, Bhusari K P \& Roy A A. Formulation , Development and evaluation of Diclofenac Sodium Gel using Water soluble Polyacrylamide Polymer. Digest J. Nanomaterials Biostructures. 2009; 4(2): 285-290.

10. Penzes T, Blazso G, Aigner Z , Falkay $G$ \& Eros I. Topical absorption of piroxicam from organogels- invitro and invivo correlations. Int. J. Pharm. 2005; 298: 47-54.

\section{How to cite this article:}

Gadad A.P., Sharma Vani, Darbha N.S., Dandagi P.M. and Singh Renu. Isolation and Purification of Exopolysaccharides and Exploring its Potential as an Excipient in the Development of Suitable Formulation. Int. J. Adv. Pharm. Biotech., 2015; 1(2): 1-8. 